„TURYZM", t. 9, z. 2, 1999

\title{
Marin Baczwarow
}

PROGRAM ZAJĘĆ DYDAKTYCZNYCH Z PRZEDMIOTU "GEOGRAFIA TURYSTYCZNA ŚWIATA" NA STUDIACH Z GEOGRAFII TURYZMU I HOTELARSTWA NA UE

LE PROGRAMME DES ACTIVITÉS DIDACTIQUES AU SUJET „GÉOGRAPHIE TOURISTIQUE DU MONDE” AUX ÉTUDES DE LA GÉOGRAPHIE DU TOURISME ET DE L'HÔTELLERIE À L'UNIVERSITÉ DE ŁÓDŹ

THE CURRICULUM OF THE 'TOURIST GEOGRAPHY OF THE WORLD' SUBJECT AT THE GEOGRAPHY OF TOURISM AND HOTEL MANAGEMENT STUDIES AT THE UNIVERSITY OF ŁÓDŹ

Jest to przedmiot obowiązkowy dla studentów IV roku specjalności z geografii turyzmu i hotelarstwa Uniwersytetu Łódzkiego; obejmuje 20 godz. wykładów i 20 godz. ćwiczeń.

Słuchacze zobowiązani są do opanowania niezbędnego zasobu wiedzy i metod analizy turystyki jako zjawiska przestrzennego na szczeblu globalnym i makroregionalnym oraz na przykładzie wybranych krajów, regionów i kurortów.

Geografia turystyczna świata bada uwarunkowania i interpretuje efekty przestrzenne turyzmu. Jej zakres jest wyjątkowo szeroki, bowiem opiera się na faktach, zjawiskach i procesach badanych przez geografię społeczno-ekonomiczną i przyrodniczą oraz na faktach, teoriach i metodach $\mathrm{z}$ warsztatu badawczego wielu innych nauk. Jak każda geograficzna wiedza, geografia turystyczna świata posiada immanentny wymiar regionalny.

Efektem zajęć winno być:

- zdobycie wiedzy o turyzmie będącym kompleksem zjawisk przestrzennych, jego rozwoju w świecie, w makroregionach turystycznych świata i w kluczowych krajach i regionach; geografia turystyczna świata korzysta z pojęć ogólnych, takich jak: turystyka, wypoczynek, turysta, ruch turystyczny, czas 
wolny, infrastruktura turystyczna itd., konfrontując je z rozwojem turystyki na konkretnym obszarze;

- opanowanie umiejętności pracy z materiałami źródłowymi (monografie, przewodniki, materiały statystyczne, artykuły, prasa, filmy, zdjęcia, mapy i atlasy, albumy i foldery $\mathrm{i}$ inne), oraz opanowanie analizy regionalnej na podstawie literatury, źródeł statystycznych, zestawień porównawczych, analizy SWOT, studiów przypadków, ankiet itd.;

- wiedza o organizacji turystyki w różnych krajach, o różnych koncepcjach rozwojowych w turystyce i strategii zarządzania przestrzennego i ich zastosowaniu w konkretnych środowiskach i sytuacjach ze szczególną uwagą zwróconą na rozwiązywanie konfliktów przestrzennych;

- ukierunkowanie nauki o turyzmie na zastosowanie praktyczne w firmach, biurach podróży, w hotelarstwie, przewodnictwie, w akcjach i placówkach promocyjnych, w organizacjach centralnych i resortowych, w urzędach wojewódzkich, powiatowych itd.

Tematem przewodnim zajęć z geografii turystycznej świata jest rozwój i organizacja przestrzenna turyzmu. W ramach zajęć - ze względu na ograniczenie czasowe - główną uwagę przywiązuję się do szczebla analizy makroregionów (uznanych przez WTO) oraz szczebla wybranych krajów. Wybór krajów został dokonany z uwagi na wiodące typy krajów pod względem rozwoju turystyki oraz ich znaczenia dla wymiany turystycznej z Polska. Inne, niższe szczeble analizy - regiony i najważniejsze centra turystyki (kurorty, uzdrowiska, miasta kultury itd.) - są omawiane tylko dla wybranych, typowych krajów. Więcej uwagi poświęca się centrom turystyki recepcyjnej na ćwiczeniach za pomocą referatów i materiałów ilustracyjnych.

Na współczesnej mapie świata znajduje się prawie 180 państw, w których nie sposób scharakteryzować zagadnienia turystyki w ciagu 20 godz. Zatem wykłady i ćwiczenia oparte są raczej na studiowaniu trendów rozwojowych, na ilustracjach i studiach przypadków, niż na wyczerpującej charakterystyce przestrzennej turyzmu na całym świecie.

Główna uwaga na zajęciach z geografii turystycznej świata ukierunkowana jest na obszary i kraje typowe, zaawansowane pod względem rozwoju turystyki i reprezentujące oryginalne modele rozwojowe. Są to przeważnie kraje europejskie.

Kontynuacją nauki z geografii turystycznej świata w programie studentów GTiH sa przedmioty do wyboru, pozwalające poznać konkretne kraje, takie jak Francja, Hiszpania, Grecja, Włochy.

Wstęp teoretyczno-terminologiczny obejmuje 4 godz. (1/5 wykładów), na charakterystykę makroregionów i subregionów WTO przeznaczone są tylko 2 godz., resztę czasu, 14 godz., zajmują charakterystyki wybranych krajów i ich regionów turystyczno-wypoczynkowych. Niżej podajemy jednostki tematyczne wykła- 
dów i ćwiczeń na przykładzie zrealizowanych zajęć w roku akademickim 1998/1999.

\section{Wyklady}

1. Wprowadzenie: cele i znaczenie przedmiotu, struktura zajęć, literatura, zadania dla studentów; 1 godz.

2. Struktura przestrzenna turystyki w przekroju światowym.

a. Ustalenia terminologiczne; 1 godz.

b. Charakterystyka stanu i rozmieszczenia turystyki światowej - lata dziewięćdziesiąte. Turystyka wewnętrzna i międzynarodowa. Główne kierunki ruchów. Trendy rozwojowe i paradygmaty (turystyka stabilizująca, ekoturystyka, wiejska, biznesowa, walorów duchowych, rozrywkowa, turystyka techniczna $\mathrm{i}$ archeologia przemysłowa $\mathrm{i}$ inne). Koncepcje w polityce turystycznej; 2 godz.

c. Charakterystyka makroregionów turystycznych świata; 2 godz.

3. Charakterystyka wybranych krajów i regionów: Wielka Brytania, Francja, Włochy, Austria, Grecja i Cypr, Bliski Wschód i Tunezja, USA i Kanada - po 2 godz.; razem 20 godz.

W odniesieniu do punktu trzeciego należy zastosować następujący plan:

1. Ogólne dane o kraju.

2. Położenie turystyczno-geograficzne.

3. Walory turystyczne (przyrodnicze, antropogeniczne, mieszane), ocena walorów.

4. Rozwój turystyki wewnętrznej i zagranicznej (ruchy, rodzaje turystyki, baza noclegowa i infrastruktura, potencjał kadrowy i kształcenie, wpływy i znaczenie turystyki dla danego kraju).

5. Regionalizacja turystyczna. Charakterystyka regionów. Główne szlaki turystyczne i centra atrakcyjności.

6. Zarządzanie i problemy marketingu i promocji.

7. Analiza SWOT turystyki (głównie na podstawie walorów, zadowolenia turystów, obsługujących i miejscowej społeczności, stan i problemy marketingu i zarządzania, problemy pojemności i stan środowiska).

8. Koncepcje i projekty. Potencjał rozwoju turystyki.

\section{II. Ćwiczenia}

1. Podanie źródeł i materiałów statystycznych WTO. Podział zadań i referatów; 1 godz.

2. Studium przypadku z historii turystyki (Dominika) - 2 referaty; 1 godz.

3. Turystyka trwała (stabilizująca), w tym: miejskie ośrodki kultury Europy - 2 referaty; 1 godz.; turystyka wiejska (zielona) - 1 referat; 1 godz.

4. Organizacja turystyki i turystyka kongresowa we Francji, Euro-Disneyland -3 referaty; 2 godz. 
5. Turystyka zagraniczna Niemców -2 referaty; 2 godz.

6. Potencjał turystyczny Europy Środkowej i Wschodniej - referaty; 2 godz.

7. Porównanie turystyki polskiej z francuską - referaty; 1 godz.

8. Turystyka na Słowacji -1 referat; 1 godz.

9. Hotelarstwo węgierskie - 1 referat; 1 godz.

10. Rozwój turystyki wybrzeży morskich -porównanie Balearów, Dalmacji i wybrzeża Morza Czarnego (Bułgaria) - 3 referaty; 2 godz.

11. Turystyka w Palestynie -1 referat; 1 godz.

12. Turystyka „małych tygrysów” -3 referaty; 2 godz.

13. Turystyka w Meksyku - 1 referat; 1 godz.

14. Podsumowanie i zaliczenie -1 godz; razem 20 godz.

Ćwiczenia są realizowane wg następującego algorytmu:

1. Czas organizacyjny (sprawdzenie obecności, ustalenia odnośnie do przyszłych referatów i źródeł).

2. Krótkie przypomnienie treści ostatniego wykładu i odpowiedzi na uprzednio zadane pytania (pisemnie lub ustnie).

3. Przedstawienie referatu (referatów), zadawanie pytań, uzupełnienia.

4. Materiały ilustrujące wykład lub referaty (filmy, przeźrocza, mapy, zdjęcia, albumy, foldery itd.).

5. Dyskusja i podsumowanie.

6. Zadania na następne zajęcie (pytania, wykresy, mapy i inne).

Uczestnicząc $w$ zajęciach $\mathrm{z}$ geografii turystycznej świata student nabiera umiejętności:

- pracy nad materiałami źródłowymi, zbierania i interpretacji informacji o turystyce $w$ przekroju przestrzennym,

- analizy regionalnej turyzmu z zastosowaniem koncepcji i pojęć ogólnonaukowych,

- porównywania i wartościowania różnych koncepcji rozwojowych w polityce turystycznej poszczególnych krajów,

- zastosowania wiedzy regionalno-geograficznej w pracy w firmie lub organizacji turystycznej, w urzędach administracji publicznej itd.,

- udziału we wszelkich akcjach promocji turystycznej, przy opracowywaniu materiałów promocyjnych i informatorów, wytyczeniu szlaków w turystyce krajowej i międzynarodowych.

\section{Literatura zalecana}

A I e j z i a k W., 1999, Turystyka w obliczu wyzwań XXI wieku, Kraków.

D e w a i 11 y J.-M., F 1 a m e n t E., 1993, Geographie du tourisme et des loisirs, SEDES, Paris.

D a v i d s o n B., 1996, Turystyka, PART, Warszawa.

G a w o r e c k i S., 1998, Turystyka, PWE, Warszawa.

K o w a I c z y k A., 1997, Geografia turyzmu, UW, Warszawa. 
K r u c z e k Z., S a c h a S., 1996, Europa-zarys geografii turystycznej, „Ostoja”, Kraków. W a r s z y ńs k a J., J a c k ow s k i A., 1978, Podstawy geografii turyzmu, PWN, Warszawa.

W a r s z y ń s k a J. (red.), 1995, Geografia turystyczna świata, cz. I, II, PWN, Warszawa.

Wy r z y k ow s k i J., L i je w ski T., M i kułow sk i M., 1985, Geografia turystyczna Polski, PWN, Warszawa.

Informatory turystyczne różnych krajów.

Statistical Yearbook of WTO (różne lata).

Prof dr hab. Marin Baczwarow

Wplynęło:

Katedra Geografii Miast i Turyzmu

Uniwersytet Łódzki

30 listopada $1999 \mathrm{r}$.

ul. Kopcińskiego 31

90-142 Łódź 